Jacek STROJNY ${ }^{1}$

\title{
STANDARDY KONTROLI ZARZĄDCZEJ - WYMIAR PRAKTYCZNY WDROŻENIA
}

Artykuł przedstawia założenia wdrożenia i doskonalenia systemu kontroli zarządczej na przykładzie JST. Jej wprowadzenie jest konsekwencją zapisów ustawy o finansach publicznych z 2009 r. Oczywiście wprowadzenie kontroli zarządczej jest także potencjalnie korzystne ze względu na możliwość zwiększenia efektywności i skuteczności procesu zarządzania. Ten właśnie punkt widzenia przyjęto w niniejszym artykule.

W pierwszej kolejności opisano założenia nowego podejścia do procesu zarządzania w wymienionych podmiotach. Skupiono się tutaj zarówno na celach kontroli zarządczej, jak i jej istocie, odwołując się do ogólnych standardów i wyznaczając na tej podstawie najważniejsze jej obszary. Niektóre z nich, jak np. zarządzanie ryzykiem są dla administracji publicznej stosunkowo nowym zagadnieniem i stanowią pewnego rodzaju wyzwanie. Wdrożenie kontroli zarządczej wymaga bowiem zmiany w rozumieniu oraz organizacji procesu zarządzania. Niestety podstawowym problemem jest to, że wprowadzając kontrolę zarządczą zwraca się powszechnie uwagę nie tyle na potrzeby w zakresie przebiegu procesu zarządzania, co na konieczność spełnienia zapisów ustawowych.

W artykule zaproponowano przykładowy zestaw standardów dostosowanych do specyfiki samorządu lokalnego. Poprzez analizę zgodności z wytycznymi Ministra Finansów oceniono także użyteczność tej propozycji i możliwość jej praktycznego wdrożenia. Podkreślić należy że schemat systemu kontroli zarządczej oparty na zbudowanej liście standardów jest podejściem ogólnym, ale jednocześnie kompleksowo obejmuje wszystkie istotne obszary zarządzania. Oczywiście wdrożenie kontroli zarządczej wymaga odpowiedniego dostosowania rozwiązań (np. określonych dokumentów, czy procedur) do specyfiki danej organizacji. Dlatego też owa ogólna koncepcja, którą przedstawiono w artykule powinna być optymalizowana w procesie wdrożenia pod katem indywidualnych potrzeb podmiotu.

Słowa kluczowe: kontrola zarządcza, samorząd terytorialny, standardy, wdrożenia

\section{WPROWADZENIE}

Jednym z zadań doskonalących, postawionych przed jednostkami sektora finansów publicznych jest wdrożenie standardów i systemowego podejścia do kontroli zarządczej. Wpisane jest ono w nowy reżim prawny wprowadzony ustawą z dnia 27 sierpnia 2009 r. o finansach publicznych. Nie ulega jednak wątpliwości, że równie ważnym czynnikiem determinującym działania podejmowane $\mathrm{w}$ tym zakresie jest zmiana wymagań stawianych instytucjom sektora finansów publicznych. W niniejszym artykule skupiono się przede wszystkim na sytuacji administracji publicznej na poziomie samorządowym, w tym w szczególności lokalnym. Nowe wyzwania rozwojowe stojące przed tego typu instytucjami w coraz większym stopniu przekładają się na sytuację samych instytucji, ale także możliwości sprawnego i efektywnego

\footnotetext{
${ }^{1}$ Dr Jacek Strojny, Katedra Ekonomii, Wydział Zarządzania, Politechnika Rzeszowska, al. Powstańców Warszawy 8, 35-959 Rzeszów, tel. 17 8651529, e-mail: jstrojny@ prz.edu.pl.
} 
przełożenia ich aktywności na możliwości rozwojowe systemu gospodarczego na poziomie gminy, powiatu czy województwa.

Należy więc przyjąć założenie, że wdrażanie i doskonalenie kontroli zarządczej to działania ukierunkowane nie tyle na wypełnienie zapisów ustawowych, co na zwiększenie konkurencyjności JST. Sprawne zarządzanie zarówno jednostkami organizacyjnymi, jak i rozwojem całej JST jest bowiem jednym z istotnych, endogenicznych czynników rozwojowych. Założenie to jest na tyle zasadne, że jego artykułowanie wydawać się może niepotrzebne. W przypadku wielu samorządów w Polsce wciąż nie udaje się wyjść poza mechanizm administracyjny, w którym wypełnienie zapisów ustawowych jest celem, a nie środkiem do realizacji celów rozwojowych. Należy zatem zastanowić się, w jaki sposób podejść do wdrożenia systemu kontroli zarządczej, aby uzyskać realne przełożenie na jakość zarządzania. Próbując odpowiedzieć na to pytanie, skupiono się na działaniu, które wydaje się tutaj fundamentalnym, tj. na sposobie identyfikacji i opisu adekwatnych standardów kontroli zarządczej. Powinien być on przeprowadzony w taki sposób, aby uzyskać realny mechanizm audytu jakości zarządzania oraz podstawę do opartego na konkretnych parametrach dyskursu nt. jakości zarządzania w danej jednostce samorządu terytorialnego.

\section{CELE I ISTOTA KONTROLI ZARZĄDCZEJ}

Sektor finansów publicznych od 2010 r. działa w reżimie ustawy z dnia 27 sierpnia 2009 r. o finansach publicznych, w której wprowadzono nowe wówczas pojęcie kontroli zarządczej ${ }^{2}$. Już w pierwszych komentarzach podkreślano, że nowe podejście nie jest rewolucją i odwołuje się do znanych i stosowanych już w samorządzie rozwiązań w zakresie kontroli wewnętrznej, w tym kontroli finansowej, czy audytu wewnętrznego. Wszystkie te rodzaje aktywności, wsparte niekiedy systemem zarządzania jakością (np. ISO), służą doskonaleniu przebiegu procesów, a więc zapewnieniu kontroli zarządczej.

Warto jednak podkreślić, że mimo tej zbieżności z istniejącymi wcześniej rozwiązaniami, koncepcja kontroli zarządczej wprowadza jednak administrację finansów w nową filozofię działania. Szczególnie jest to istotne w kilka lat po wprowadzeniu omawianych przepisów, kiedy coraz wyraźniej zwraca się uwagę na konieczność uwzględnienia nowych warunków funkcjonowania i rozwoju systemów gospodarczych. Zarówno kryzys światowy, jak i wyraźnie zarysowujące się procesy globalizacji i regionalizacji intensyfikują dyskusję na temat endoi egzogenicznych determinant rozwoju zarówno na poziomie Europy, Polski, regionów, powiatów czy gmin. Konieczność podejmowania coraz bardziej wyrafinowanych działań w celu zwiększenia konkurecyjności na rynkach kapitału mobilnego karze poszukiwać rozwiązań zwiększających skuteczność i efektywność działania. Na nowo należy sobie zadać pytanie, czy proces zarządzania realizowany jest w sposób zapewniający nie tylko uzyskanie zgodności z przepisami prawa, ale także wysokiej sprawności poszczególnych jednostek organizacyjnych, jak i optymalnego wykorzystania potencjałów i szans rozwojowych.

Zarówno wprowadzenie standardów kontroli zarządczej, jak i doskonalenie sposobów ich zapewnienia powinno stać się okazją do szerszego spojrzenia na zmieniającą się rolę administracji publicznej (szczególnie samorządowej) w nowoczesnej gospodarce. Proces zarządzania w tego typu instytucjach musi ewoluować w kierunku rozwiązań charakterystycznych dla biznesu. Dzięki zastosowaniu metod zarządzania czy podejść (np. zarządzanie przez cele, zarządzanie projektami, zarządzanie jakością public relations) uzyskuje się bowiem narzędzia

\footnotetext{
${ }^{2}$ Ustawa z dnia 27 sierpnia 2009 r. o finansach publicznych, DzU nr 157, poz. 1240, ze zm.
} 
niezbędne do zwiększania zdolności konkurencyjnych. Tego typu ujęcie stanowi już znaczne wyzwanie dla samorządów i z cała pewnością nie zostanie upowszechnione w najbliższych latach. Warto zwrócić chociażby uwagę na potencjalne korzyści dla kontroli zarządczej, wynikające z wprowadzenia budżetu zadaniowego. Oprócz oczywistego wpływu na przejrzystość gospodarki finansowej, pozwala on na czytelną identyfikację i monitoring celów oraz ocenę sprawności ich realizacji. Jest on także źródłem ważnych informacji zarządczych, które można wykorzystać w procesie decyzyjnym, odpowiednio reagując na zdiagnozowane odchylenia od planów.

Podsumowując, istotą kontroli zarządczej w samorządzie jest doprowadzenie do jak najlepszego wykonywania zadań ustawowych oraz innych zadań wynikających z potrzeb rozwojowych jednostki. Podstawowe parametry jakości zarządzania, wyeksponowane $\mathrm{w}$ ustawie o finansach publicznych, to: zgodność z prawem, efektywność, oszczędność oraz terminowość ${ }^{3}$. Na tej podstawie sformułowano także postulaty dotyczące ogólnych celów kontroli zarządczej, wśród których należy wymienić zapewnienie ${ }^{4}$ :

- zgodności działalności z przepisami prawa oraz procedurami wewnętrznymi,

- skuteczności i efektywności działania,

- wiarygodności sprawozdań,

- ochrony zasobów,

- przestrzegania i promowania zasad etycznego postępowania;

- efektywności i skuteczności przepływu informacji,

- zarządzania ryzykiem.

Wprowadzenie celów związanych ze skutecznością i efektywnością działania stanowi zachętę do weryfikacji zdolności danej jednostki do wyznaczania celów na poziomie strategicznym i operacyjnym. Obserwuje się tutaj dość dużą trudność w integracji wymiaru dłogoi krótkookresowego, co utrudnia optymalizację działań w pod kątem wymienionych parametrów sprawności. Podobnie, relatywnie dużym wyzwaniem może być połączenie zarządzania przez cele ze skutecznym zarządzaniem ryzykiem zarówno w odniesieniu do obszaru finansowego, ochrony zasobów, jak i przyjętych celów rozwojowych.

\section{WYTYCZNE MINISTRA FINANSÓW W ZAKRESIE STANDARDÓW KON- TROLI ZARZĄDCZEJ}

W ustawie o finansach publicznych wskazano zadania Ministra Finansów w zakresie koordynacji kontroli zarządczej w jednostkach sektora finansów publicznych. Jednym z najważniejszych jest określenie i upowszechnienie standardów związanych z realizacją tego procesu. Komunikat nr 23 Ministra Finansów z dnia 16 grudnia 2009 r. w sprawie standardów kontroli zarzqdczej dla sektora finansów publicznych określa te wymagania w dwudziestu dwóch standardach sklasyfikowanych w pięciu grupach ${ }^{5}$ :

- A. Środowisko wewnętrzne,

- B. Cele i zarząadzanie ryzykiem,

- C. Mechanizmy kontroli,

- D. Informacja i komunikacja,

\footnotetext{
${ }^{3}$ Tamże.

${ }^{4}$ Tamże.

${ }^{5}$ Komunikat nr 23 Ministra Finansów z dnia 16 grudnia 2009 r. w sprawie standardów kontroli zarządczej dla sektora finansów publicznych, DzUrz. Min. Fin. nr 15, poz. 84.
} 
- E. Monitorowanie i ocena.

Pierwszy z wymienionych obszarów zwraca uwagę na konieczność odpowiedniego oddziaływania na środowisko wewnętrzne jednostek organizacyjnych JST. Konieczne jest zbudowanie i przestrzeganie systemu wartości etycznych. Dzięki temu uzyskuje się odpowiednie warunki społeczne, składające się na kapitał społeczny (relacyjny), zarówno w stosunkach pracownik - pracodawca, jak i urząd - klient. Ważny jest także kapitał intelektualny i odpowiednie jego kształtowanie poprzez doskonalenie kompetencji zawodowych zarówno w kierunku dostosowania do zadań na poszczególnych stanowiskach, jak i wyzwań, przed którymi stoi dany samorząd. Warto zwrócić także uwagę na odpowiednie uporządkowanie relacji formalnych w poszczególnych jednostkach. Wiąże się to ze zbudowaniem pewnego kompleksowego systemu określającego podział pracy. Wymaga to odpowiedniego przygotowania takich dokumentów, jak Regulamin organizacyjny, Schemat organizacyjny, czy Opis stanowiska pracy oraz Zakres obowiqzków pracownika. Należy dążyć nie tylko do czytelnego podziału zadań i przypisania odpowiedzialności, ale także do poszukiwania optymalnego z punktu widzenia danej jednostki organizacyjnej poziomu delegacji uprawnień.

W ramach kolejnej grupy standardów określono zasady formułowania i monitorowania celów oraz zarządzania ryzykiem. Ta grupa standardów jest szczególnie istotna ze względu na znaczny potencjał rozwojowy samorządów w odniesieniu do wymienionego obszaru. Wprowadzenie metody ZPC (zarządzanie przez cele) do praktyki jednostek samorządowych wciąż napotyka na znaczne trudności kompetencyjne i narzędziowe, zarówno na poziomie strategicznym, jak i operacyjnym. Tymczasem, to właśnie w tutaj należy upatrywać fundamentu skutecznego i efektywnego zarządzania, a przecież taki postulat stoi za wprowadzaniem standardów kontroli zarządczej. Podobnie rzecz wygląda, jeśli chodzi o wykorzystanie zarządzania ryzykiem, zarówno w zakresie identyfikacji, analizy skutków, jak i programowania reakcji na zagrożenia.

Stosunkowo dobrze utrwalone są natomiast zasady związane $\mathrm{z}$ zapewnieniem kolejnej grupy standardów, dotyczących mechanizmów kontroli, w szczególności w zakresie kontroli operacji finansowych i gospodarczych, ochrony zasobów czy zapewnienia ciagłości działania. Wprowadzane są także polityki bezpieczeństwa informacji oraz inne działania związane $\mathrm{z}$ kontrolą systemów informatycznych. W wytycznych Ministra Finansów znajdują się jednak także sugestie dotyczące obszarów, które wciąż wymagają jeszcze doskonalenia. Chodzi tutaj o umiejętność dokumentowania systemu kontroli zarządczej, a więc poprawnego opisu sposobu zapewnienia standardów. Zadaniem każdej jednostki jest takie zbudowanie całego mechanizmu, aby uzyskać pozytywny efekt w postaci optymalizacji procesu zarządzania pod kątem specyficznych jej warunków wewnętrznych i zewnętrznych.

Bardzo ważnym elementem kontroli zarządczej jest także sprawność procesów komunikacji i informowania. Do tego nawiązuje kolejna grupa standardów, w których wskazuje się na konieczność zapewnienia bieżącej i adekwatnej informacji zarówno na stanowiskach kierowniczych, jak i wykonawczych. Bardzo ważne jest stworzenie sprawnego systemu informowania kierownictwa o stopniu realizacji celów strategicznych i operacyjnych. Dzięki temu zyskuje się możliwość korygowania podjętych decyzji i reagowania na odchylenia od planów realizacji strategii, czy zadań operacyjnych. Oczywiście ważne jest także zbudowanie sprawnego systemu komunikowania się $\mathrm{z}$ otoczeniem. Nie tylko chodzi o realizację zadań związanych $\mathrm{z}$ udostępnianiem informacji publicznej, ale także $\mathrm{z}$ nowoczesną, skoordynowaną polityką oddziaływania na społeczność lokalną oraz przedsiębiorstwa. Tego typu działania mogą mieć kolosalny wpływ na wizerunek JST oraz poszczególnych jej jednostek organizacyjnych. 
Piąta grupa standardów stworzona została z myślą o mechanizmie doskonalenia systemu kontroli zarządczej. Należy bowiem podkreślić, że wdrożenie standardów kontroli zarządczej nie powinno być rozpatrywane w kategoriach jednorazowego przedsięwzięcia, ale raczej procesu ciagłego. Wprowadzenie procedur monitorowania i samooceny oraz audytu ukierunkowany na podnoszenie jakości zarządzania stwarza warunki do dyskusji na ten temat i poszukiwania obszarów niedoskonałości. Umiejętne wprowadzenie tych standardów powoduje, że zagadnienie kontroli zarządczej przestaje być wyłącznie reakcją na wymagania ustawowe, a staje się realnym mechanizmem oddziaływania na przebieg wewnętrznych procesów.

Nie ulega wątpliwości, że zarówno ustawa o finansach publicznych, jak i standardy określone w wytycznych Ministra Finansów stanowić powinny główny punkt odniesienia dla rozwiązania wprowadzonego $\mathrm{w}$ danej jednostce samorządowej. Jednocześnie jednak implementacja wprost ogólnych standardów, bez ich dostosowania do specyfiki jednostki może okazać się zabiegiem niewystarczającym do faktycznego oddziaływania na jakość procesu zarządzania. Dlatego też należy poszukiwać takiej formuły opisu standardów oraz ich zapewnienia, która odpowiada na zidentyfikowane problemy zarządcze, które mimo ogólnych tendencji, charakterystycznych dla całego sektora samorządowego, mają jednak przede wszystkim wymiar indywidualny. Takie podejście właśnie przyjęto w niniejszym artykule, formułując listę dwunastu standardów oraz odnosząc je zarówno do wytycznych ministra finansów, jak i konfrontując $\mathrm{z}$ celami kontroli zarządczej.

\section{PRZYKLAD DEDYKOWANEGO SYSTEMU STANDARDÓW KONTROLI ZA- RZĄDCZEJ DLA JST}

Jednym ze sposobów opisu standardów kontroli zarządczej w danej jednostce samorządu terytorialnego może być dokument pt. Księga standardów kontroli zarzqdczej. Powinien on precyzować w jaki sposób zapewnia się odpowiednią jakość, a więc skuteczność i efektywność zarządzania. W niniejszym artykule przedstawiono zarys takiego dokumentu, przygotowując dwanaście standardów bazujących na wytycznych Ministra Finansów, zawartych w Komunikacie nr 23 Ministra Finansów z dnia 16 grudnia 2009 r. w sprawie standardów kontroli zarządczej dla sektora finansów publicznych. Dążąc do zapewnienia adekwatnej, efektywnej i skutecznej kontroli zarządczej można sformułować następujące standardy:

- S.1. Określanie i monitorowanie celów

- S.2. Struktura organizacyjna.

- S.3. Polityka personalna i rozwój kompetencji.

- S.4. Etyka.

- S.5. Decentralizacja i delegowanie uprawnień.

- S.6. Identyfikacja ryzyka i przeciwdziałanie.

- S.7. Informowanie i komunikowanie.

- S.8. Nadzór.

- S.9. Kontrola operacji finansowych i gospodarczych.

- S.10. Ochrona zasobów.

- S.11. Ochrona informacji.

- S.12. Mechanizmy kontroli zarządczej.

Charakterystykę wymienionych standardów przedstawiono w tabeli 1., określając proponowaną ich treść oraz cel. Dzięki takiemu podejściu możliwe jest stworzenie mechanizmu doskonalenia procesu zarządzania. Powinien on polegać na zdefiniowaniu mierników odwołujących się do celu danego standardu i pozwalających na ocenę stopnia zapewnienia kontroli 
zarządczej. Umożliwia to przeprowadzenie audytu opartego na pomiarze określonych parametrów, dostosowywanych do aktualnej sytuacji jednostki i uzupełnianych w miarę osiagania coraz wyższej jakości zarządzania. Dodatkowym uzupełnieniem takiego podejścia powinno być wskazanie osoby odpowiedzialnej za cel standardu.

Tabela 1. Opisy standardów kontroli zarządczej

\begin{tabular}{|c|c|}
\hline \multicolumn{2}{|r|}{ Standard S.1. Określanie i monitorowanie celów } \\
\hline Treść: & $\begin{array}{l}\text { Wyznacza się precyzyjne cele, zgodnie z kryterium SMART, zarówno na poziomie strategicznym, jak } \\
\text { i operacyjnym. Każda jednostka organizacyjna gminy ma precyzyjnie określone cele, za których realizację } \\
\text { odpowiada jasno wskazana osoba. Stosuje się pomiar oraz ocenę stopnia realizacji celów w sposób za- } \\
\text { pewniający uzyskanie informacji wystarczającej do prawidłowego podejmowania decyzji przy jednocze- } \\
\text { śnie akceptowalnym poziomie kosztów monitorowania. }\end{array}$ \\
\hline Cel: & $\begin{array}{l}\text { Gmina dysponuje kompleksowym i dostosowanym do swojej specyfiki systemem celów, obejmującym } \\
\text { poziom strategiczny i operacyjny zarządzania oraz stosuje narzędzia pozwalające na monitorowanie } \\
\text { i ocenę stopnia ich realizacji. }\end{array}$ \\
\hline \multicolumn{2}{|r|}{ Standard S.2. Struktura organizacyjna } \\
\hline Treść: & $\begin{array}{l}\text { W regulaminie organizacyjnym określa się precyzyjnie podział zadań pomiędzy komórkami organizacyj- } \\
\text { nymi, precyzując w szczególności odpowiedzialność kluczowych stanowisk kierowniczych. Strukturę } \\
\text { organizacyjną przedstawia się w postaci schematu organizacyjnego. Prowadzi się także dokumentację } \\
\text { personalną, precyzując zakres obowiązków dla każdego pracownika oraz opis każdego stanowiska pracy. }\end{array}$ \\
\hline Cel: & $\begin{array}{l}\text { Wszystkie jednostki organizacyjne gminy sprawnie organizują pracę pracowników, określając uprawnie- } \\
\text { nia, zadania do wykonania oraz odpowiedzialność. }\end{array}$ \\
\hline \multicolumn{2}{|r|}{ Standard S.3. Polityka personalna i rozwój kompetencji } \\
\hline Treść: & $\begin{array}{l}\text { Prowadzi się spójną i kompleksową politykę rozwojową, obejmującą planowanie szkoleń dostosowane do } \\
\text { potrzeb jednostki organizacyjnej oraz zgodne z indywidualną ścieżką rozwoju zawodowego pracowni- } \\
\text { ków. Jasno określa się formalne kierunki rozwoju zawodowego, uwzględniając konieczne uzupełnienia } \\
\text { wiedzy (wykształcenie i trening specjalistyczny). Wyznacza się wymagania względem kandydatów na } \\
\text { stanowisko pracy na podstawie wymagań wynikających z opisu wakującego stanowiska pracy. Stosuje się } \\
\text { kompleksowy system motywowania, w którym ocena okresowa wiąże się z określeniem kierunków } \\
\text { rozwoju pracownika, zaś w ramach oceny bieżącej wyznacza się i weryfikuje stopień osiagnięcia celów, } \\
\text { dążąc do podwyższenia jakości kapitału pracy. Dążąc do utrzymania optymalnego poziomu zaangażowa- } \\
\text { nia bada się cyklicznie klimat organizacyjny i poziom zadowolenia pracowników. }\end{array}$ \\
\hline Cel: & W jednostkach organizacyjnych gminy prowadzi się czytelną i prorozwojową politykę personalną. \\
\hline \multicolumn{2}{|r|}{ Standard S.4. Etyka } \\
\hline Treść: & $\begin{array}{l}\text { W gminie prowadzi się jawną i czytelną politykę personalną. Zasady wynagradzania, oceny pracy oraz } \\
\text { doboru pracowników na wolne stanowiska pracy są jasne i konsekwentnie stosowane. Nie występują } \\
\text { nadużycia przy wydawaniu środków publicznych oraz realizacji usług publicznych. }\end{array}$ \\
\hline Cel: & $\begin{array}{l}\text { Wartości etyczne znajdują odzwierciedlenie w polityce personalnej w gminie oraz sposobie wydatkowania } \\
\text { pieniędzy publicznych oraz świadczenia usług publicznych. }\end{array}$ \\
\hline \multicolumn{2}{|r|}{ Standard S.5. Decentralizacja i delegowanie uprawnień } \\
\hline Treść: & $\begin{array}{l}\text { Deleguje się odpowiedzialność i uprawnienia do poziomu optymalnego z punktu widzenia skuteczności } \\
\text { zarządzania i zgodnego z przepisami prawa. Precyzyjnie określa się zakres delegowanych uprawnień, } \\
\text { uwzględniając go w opisach stanowisk pracy oraz rejestrze upoważnień i pełnomocnictw. Monitoruje się } \\
\text { jakość procesów decyzyjnych doprowadzając do pełnej zgodności pomiędzy formalną delegacją upraw- } \\
\text { nień a rzeczywistym przebiegiem procesów decyzyjnych. }\end{array}$ \\
\hline Cel: & $\begin{array}{l}\text { Zakres delegowanych uprawnień jest precyzyjnie określony, a przeniesienie uprawnień i odpowiedzialno- } \\
\text { ści odzwierciedlony jest w faktycznym przebiegu procesów decyzyjnych. }\end{array}$ \\
\hline \multicolumn{2}{|r|}{ Standard S.6. Identyfikacja ryzyka i przeciwdzialanie } \\
\hline Treść: & $\begin{array}{l}\text { Systematycznie identyfikuje się ryzyka związane z realizacją zadań gminy, prowadząc jednolitą dla } \\
\text { wszystkich jednostek w gminie strukture podziału ryzyk (klasyfikację). Ocenia się prawdopodobieństwo } \\
\text { ich wystapienia oraz siłę oddziaływania ze szczególnym uwzględnieniem wpływu na możliwość osiagnię- } \\
\text { cia przyjętych celów. Podejmuje się spójne i skoordynowane działania zapobiegawcze w celu zwiększenia } \\
\text { prawdopodobieństwa realizacji pożądanego scenariusza. }\end{array}$ \\
\hline Cel: & $\begin{array}{l}\text { Skutecznie zarządza się ryzykiem na poziomie gminy, jednostek organizacyjnych oraz istotnych przed- } \\
\text { sięwzięć. }\end{array}$ \\
\hline \multicolumn{2}{|r|}{ Standard S.7. Informowanie i komunikowanie } \\
\hline
\end{tabular}




\begin{tabular}{|c|c|}
\hline Treść: & $\begin{array}{l}\text { Jasno precyzuje się kanały informacji formalnej. Tworzy się warunki do swobodnego przepływu informa- } \\
\text { cji pomiędzy pracownikami. Informacja dostarczana jest w formie adekwatnej do potrzeb danego stanowi- } \\
\text { ska, a więc dostosowanej do realizowanych zadań. Informacja dostarczana jest terminowo, pozwalając na } \\
\text { skuteczną reakcję na zjawiska wewnętrzne i zewnętrzne. }\end{array}$ \\
\hline Cel: & Pracownicy dysponują informacją adekwatną i terminową. \\
\hline \multicolumn{2}{|r|}{ Standard S.8. Nadzór } \\
\hline Treść: & $\begin{array}{l}\text { Koordynuje się politykę nadzoru w skali całej gminy, pozyskując informację na temat poziomu zapewnie- } \\
\text { nia efektywności i skuteczności działań oraz ich zgodności z przepisami prawa, standardami oraz przepi- } \\
\text { sami i procedurami wewnętrznymi. Precyzyjnie określa się i realizuje zadania w tym względzie w szcze- } \\
\text { gólności w zakresie nadzoru nad jednostkami, kontroli instytucjonalnej oraz kontroli funkcjonalnej. }\end{array}$ \\
\hline Cel: & $\begin{array}{l}\text { Zadania realizuje się efektywnie, skutecznie, zgodnie z przepisami prawa, standardami oraz przepisami } \\
\text { i procedurami wewnętrznymi. }\end{array}$ \\
\hline \multicolumn{2}{|r|}{ Standard S.9. Kontrola operacji finansowych i gospodarczych } \\
\hline Treść: & $\begin{array}{l}\text { Rzetelnie, prawidłowo i terminowo rejestruje się wszystkie operacje finansowe i gospodarcze. Upoważ- } \\
\text { nione osoby weryfikują je i zatwierdzają przed, w trakcie i po realizacji. }\end{array}$ \\
\hline Cel: & $\begin{array}{l}\text { Gmina dysponuje mechanizmami kontroli zapewniającymi, że wszystkie operacje finansowe i gospodar- } \\
\text { cze są rejestrowane rzetelnie, prawidłowo i w terminach oraz są weryfikowane i zatwierdzane przez } \\
\text { upoważnione osoby przed, w trakcie i po realizacji. }\end{array}$ \\
\hline \multicolumn{2}{|r|}{ Standard S.10. Ochrona zasobów } \\
\hline Treść: & $\begin{array}{l}\text { Dostęp do zasobów jednostki mają tylko osoby upoważnione. Właściwie chroni się i wykorzystuje zasoby } \\
\text { jednostki. }\end{array}$ \\
\hline Cel: & $\begin{array}{l}\text { Gmina dysponuje mechanizmami zapewniającymi, że dostęp do zasobów jednostki mają tylko upoważ- } \\
\text { nione osoby oraz zapewniona jest ochrona i właściwe wykorzystanie tych zasobów. }\end{array}$ \\
\hline \multicolumn{2}{|r|}{ Standard S.11. Ochrona informacji } \\
\hline Treść: & $\begin{array}{l}\text { Zapewnia się bezpieczeństwo dostępu do systemów informatycznych oraz przetwarzania danych osobo- } \\
\text { wych, informacji niejawnych oraz innych danych szczegółowych z poszczególnych zakresów aktywności } \\
\text { jednostki. Wprowadza się regulacje określające procedurę udzielania dostępu do w/w zasobów oraz } \\
\text { rozwiązania techniczne zapewniające utrzymanie optymalnego poziomu bezpieczeństwa. }\end{array}$ \\
\hline Cel: & $\begin{array}{l}\text { Gmina dysponuje mechanizmami zapewniającymi, bezpieczeństwo i ciagłości funkcjonowania jednostki } \\
\text { w zakresie przetwarzania danych, w tym w systemach informatycznych. }\end{array}$ \\
\hline \multicolumn{2}{|r|}{ Standard S.12. Mechanizmy kontroli zarządczej } \\
\hline Treść: & $\begin{array}{l}\text { Prowadzi się rejestr dokumentów stanowiących dokumentację kontroli zarządczej w podziale na doku- } \\
\text { menty regulujące sposób zapewnienia standardów kontroli zarządczej oraz dokumenty zapewniające } \\
\text { realizację standardów kontroli zarządczej. System kontroli monitorowany jest z uwzględnieniem poziomu } \\
\text { zapewnienia poszczególnych standardów. Minimum raz do roku prowadzona jest samoocena systemu } \\
\text { kontroli zarządczej, a jej efekty przekładają się na plany doskonalenia oraz są dokumentowane. Efektem } \\
\text { oceny jest zapewnienie o stanie kontroli zarządczej. }\end{array}$ \\
\hline Cel: & Zapewnienie prawidłowego przebiegu oraz doskonalenia kontroli zarządczej w długim okresie. \\
\hline
\end{tabular}

Źródło: Opracowanie własne.

Opierając się na zidentyfikowanych celach poszczególnych standardów można przygotować narzędzie badawcze Karta oceny poziomu zapewnienia standardów kontroli zarzadczej (tabela 2.), które stanowi uzupełnienie opisów. W niniejszym artykule przedstawiono przykładowe parametry dla poszczególnych standardów. Należy je traktować jako pewnego rodzaju punkt startu w procesie doskonalenia kontroli zarządczej.

Tabela 2. Schemat narzędzia do pomiaru poziomu zapewnienia standardów kontroli zarządczej

\section{KARTA OCENY POZIOMU ZAPEWNIENIA STANDARDÓW KONTROLI ZARZADCZEJ}

\begin{tabular}{clcc} 
& \multicolumn{1}{c}{ Standard S.1. Określanie i monitorowanie celów } & \\
PS.1.1. & $\begin{array}{l}\text { W strategii sformułowana jest misja, określająca główny cel do którego } \\
\text { dąży gmina w przyjętej perspektywie strategicznej. }\end{array}$ & $\square$ tak & $\square$ nie \\
PS.1.2.1. & $\begin{array}{l}\text { Istnieje min. jeden miernik, za pomocą którego można ocenić poziom } \\
\text { realizacji każdego z przyjętych celów strategicznych. }\end{array}$ & $\square$ tak & $\square$ nie \\
PS.1.2.2. & $\begin{array}{l}\text { Wyznaczono datę osiagnięcia każdego z przyjętych celów strategicz- } \\
\text { nych. }\end{array}$ & $\square$ tak & $\square$ nie \\
PS.1.2.3. & Określono zadania, których wykonanie ma służyć osiągnięciu każdego z & $\square$ tak & $\square$ nie
\end{tabular}


przyjętych celów strategicznych.

PS.1.2.4. Wyznaczono osobę odpowiedzialną za osiagnięcie każdego z przyjętych celów strategicznych.

PS.1.3.1. Wyznaczono termin zakończenia realizacji dla każdego z zadań inwestycyjnych.

PS.1.3.2. Wyznaczono planowaną wartość budżetu dla każdego z zadań inwestycyjnych.

PS.1.3.3. Wyznaczono osobę odpowiedzialną za wykonanie zadania inwestycyjnego lub jego części realizowanej przez gminę.

PS.1.4. Wszystkie zadania inwestycyjne oceniane są pod kątem zgodności ze strategią. Ocena ta zamieszczana jest w uzasadnieniu do uchwały budżetowej gminy lub do zmiany uchwały budżetowej gminy.

PS.1.5. Budżet gminy przedstawia się $\mathrm{w}$ ujęciu zadań wraz $\mathrm{z}$ przypisanymi do nich celami, które należy osiągnąc za pomocą wydatków przeznaczonych na to zadanie oraz osobą odpowiedzialną.

\section{Okreslanie i monitorowanie celów}

PS.2.1. Każda jednostka organizacyjna gminy dysponuje aktualnym regulaminem organizacyjnym.

PS.2.2.1. Każda jednostka organizacyjna przedstawia w regulaminie organizacyjnym podział na komórki organizacyjne.

PS.2.2.2. Każda jednostka organizacyjna przedstawia w regulaminie organizacyjnym zadania przypisane do poszczególnych komórek organizacyjnym.

PS.2.2.3. Każda jednostka organizacyjna określa w regulaminie organizacyjnym odpowiedzialność dla kluczowych stanowisk kierowniczych.

PS.2.2.4 Każda jednostka organizacyjna przygotowuje jako załącznik do regulaminu schemat organizacyjny w postaci grafu i/lub tabeli ze szczegółowością do poziomu stanowiska pracy.

PS.2.3.1. W każdej jednostce organizacyjnej przygotowany jest opis stanowiska dla każdego stanowiska pracy.

PS.2.3.2 W każdej jednostce organizacyjnej przygotowany jest zakres czynności dla każdego pracownika.

\section{PS.3.1 Standard S.3. Polityka personalna i rozwój kompetencji} Każda jednostka organizacyjna gminy prowadzi plan szkoleń pracowników.

PS.3.2.1 Wszystkie jednostki organizacyjne określają w opisie stanowiska pracy kierunki awansu pionowego i poziomego.

PS.3.2.2. Wszystkie jednostki organizacyjne określają w opisie stanowiska pracy formalne i preferowane warunki wykształcenia.

PS.3.2.3. Wszystkie jednostki organizacyjne określają w opisie stanowiska pracy preferowany trening specjalistyczny pozwalający podwyższyć efektywność i skuteczność pracy na stanowisku.

PS.3.3. Wszystkie jednostki organizacyjne stosują w procesie doboru pracownika wymagania wynikające z przyjętego opisu dla wakującego stanowiska pracy.

PS.3.4. Na podstawie okresowej oceny pracowniczej podejmuje się wiążące decyzje dotyczące dalszych kierunków rozwoju pracownika.

PS.3.5. Cyklicznie dokonuje się pomiaru i oceny klimatu organizacyjnego i

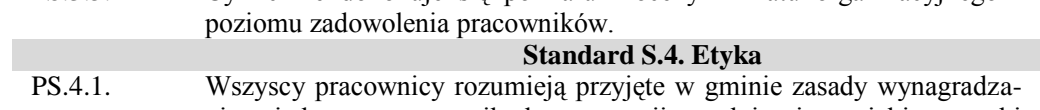
nia, wiedzą z czego wynika kwota pensji zasadniczej oraz jakie warunki należy spełnić, aby uzyskać premię lub inne korzyści przewidziane $\mathrm{w}$ systemie motywowania.

PS.4.2. Wszyscy pracownicy rozumieją przyjęte $\mathrm{w}$ gminie zasady oceny pracowniczej oraz wynikające z niej konsekwencje.

PS.4.3. Minimum 95\% pracowników jest przekonanych o tym, że polityka wynagradzania i ocena pracownicza są czytelne, uczciwe i stosowane bez odstępstw. 
PS.4.4. We wszystkich przypadkach zatrudnienie nowego pracownika odbywa się zgodnie z prawem, zapewniając jasne i uczciwe warunki rywalizacji wszystkim kandydatom na stanowisko pracy.

PS.4.5. We wszystkich przypadkach wydawanie środków publicznych odbywa się zgodnie z prawem oraz zasadą racjonalnego gospodarowania.

PS.4.6. We wszystkich przypadkach świadczenie usług publicznych odbywa się $\quad \square$ tak $\quad \square$ nie
zgodnie z prawem oraz w trosce o jakość obsługi klienta (interesanta). zgodnie z prawem oraz w trosce o jakość obsługi klienta (interesanta).

Standard S.5. Decentralizacja i delegowanie uprawnień
PS.5.1. Opisy stanowiska pracy uwzględniają informację na temat odpowiedzialności i uprawnień pracownika charakterystycznych dla jego stanowiska.

Dokumentowane są wszystkie dodatkowe upoważnienia i pełnomocnicDokumentowane są wszyst
twa udzielane pracownikom

$\square$ tak $\square$ nie

$\square$ tak $\square$ nie

$\square$ tak $\square$ nie

$\square$ tak $\square$ nie

PS.5.3. Minimum 95\% pracowników jest przekonanych, że poziom decentrali-

$\square$ tak $\square$ nie zacji jest optymalny, a formalna delegacja uprawnień i odpowiedzialności jest zgodna $\mathrm{z}$ faktycznym przebiegiem procesów decyzyjnych.

$\begin{array}{lll} & \text { Standard S.6. Identyfikacja ryzyka i przeciwdzialanie } \\ \text { PS.6.1. } & \text { Zarządza sie ryzykiem dotyczacym realizacji uchwały budżetowej }\end{array}$ dokumentując identyfikację ryzyk, ocenę oraz planowanie i realizacje działań zaradczych.

PS.6.2. Wszystkie jednostki organizacyjne gminy zarządzają ryzykiem związanym z realizacją przydzielonych im zadań dokumentując identyfikację ryzyk, ocenę oraz planowanie i realizację działań zaradczych.

PS.6.3. Wszystkie przedsięwzięcia (projekty) o wartości powyżej $0,5 \mathrm{mln}$ zł lub czasie trwania dłuższym niż 2 lata objęte są pełną procedurą zarządzania ryzykiem, obejmująca dokumentację identyfikacji ryzyka, oceny oraz planowanie i realizacji działań zaradczych.

PS.6.4. Wyodrębnia się i analizuje ryzyka związane z zapewnieniem ciągłości działania jednostki samorządu terytorialnego oraz określa możliwe scenariusze reakcji.

\begin{tabular}{|c|c|c|c|}
\hline \multicolumn{4}{|c|}{ Standard S.7. Informowanie i komunikowanie } \\
\hline PS.7.1. & $\begin{array}{l}\text { Regulamin organizacyjny oraz schemat organizacyjny każdej jednostki } \\
\text { organizacyjnej zawiera informacje pozwalające na określenie formal- } \\
\text { nych kanałów przepływu informacji. }\end{array}$ & $\square$ tak & $\square$ nie \\
\hline PS.7.2. & $\begin{array}{l}\text { Minimum } 95 \% \text { pracowników nie odczuwa istotnych barier komunikacji } \\
\text { zarówno poziomej, jak i pionowej. }\end{array}$ & $\square$ tak & $\square$ nie \\
\hline \multicolumn{4}{|c|}{ Standard S.8. Nadzór } \\
\hline PS.8.1. & $\begin{array}{l}\text { Wszystkie jednostki organizacyjne gminy objęte są nadzorem, a jego } \\
\text { przebieg jest dokumentowany. }\end{array}$ & $\square$ tak & $\square$ nie \\
\hline PS.8.2. & $\begin{array}{l}\text { Kontrola wewnętrzna doprowadza do uzyskania rzetelnego zapewnienia, } \\
\text { że system funkcjonuje zgodnie z prawem, standardami, wewnętrznymi } \\
\text { przepisami i procedurami oraz służy wytyczonym celom. }\end{array}$ & $\square$ tak & $\square$ nie \\
\hline PS.8.3. & $\begin{array}{l}\text { Kontrola funkcjonalna wykonywana jest przez wszystkich pracowników } \\
\text { w zakresie wynikającym z zajmowanego stanowiska pracy. }\end{array}$ & $\square$ tak & $\square$ nie \\
\hline \multicolumn{4}{|c|}{ Standard S.9. Kontrola operacji finansowych i gospodarczych } \\
\hline PS.9.1. & $\begin{array}{l}\text { Wszystkie procesy związane } \mathrm{z} \text { pobieraniem i gromadzeniem środków } \\
\text { publicznych realizowane są zgodnie z przyjętymi regulacjami. }\end{array}$ & $\square$ tak & $\square$ nie \\
\hline PS.9.2. & $\begin{array}{l}\text { Wszystkie procesy związane z zaciagganiem zobowiązań finansowych i } \\
\text { dokonywaniem wydatków realizowane są zgodnie z przyjętymi regula- } \\
\text { cjami. }\end{array}$ & $\square$ tak & $\square$ nie \\
\hline PS.9.3. & $\begin{array}{l}\text { Wszystkie procesy związane z udzielaniem zamówień publicznych } \\
\text { realizowane są zgodnie z przyjętymi regulacjami. }\end{array}$ & $\square$ tak & $\square$ nie \\
\hline PS.9.4. & $\begin{array}{l}\text { Wszystkie procesy związane ze zwrotem środków publicznych realizo- } \\
\text { wane są zgodnie z przyjętymi regulacjami. }\end{array}$ & $\square$ tak & $\square$ nie \\
\hline \multicolumn{4}{|c|}{ Standard S.10. Ochrona zasobów } \\
\hline
\end{tabular}




\begin{tabular}{|c|c|c|c|}
\hline & & & \\
\hline PS.10.2. & $\begin{array}{l}\text { Wszystkie procesy związane z gospodarką zapasami realizowane są } \\
\text { zgodnie z przyjętymi regulacjami. }\end{array}$ & $\square$ tak & $\square$ nie \\
\hline PS.10.3. & $\begin{array}{l}\text { Wszystkie procesy związane z gospodarką aktywami trwałymi realizo- } \\
\text { wane są zgodnie z przyjętymi regulacjami. }\end{array}$ & $\square$ tak & $\square$ nie \\
\hline PS.10.4. & $\begin{array}{l}\text { Wszystkie procesy związane z przeprowadzaniem i rozliczaniem inwen- } \\
\text { taryzacji realizowane są zgodnie z przyjętymi regulacjami. }\end{array}$ & $\square$ tak & $\square$ nie \\
\hline \multicolumn{4}{|c|}{ Standard S.11. Ochrona informacji } \\
\hline PS.11.1. & $\begin{array}{l}\text { Stosuje się mechanizmy kontroli systemów informatycznych poprzez } \\
\text { kodowanie dostępu, określanie zakresów uprawnień i ich zasad ich } \\
\text { przekazywania, przygotowywanie i aktualizowanie haseł oraz zabezpie- } \\
\text { czanie zasobów i danych przed utratą. }\end{array}$ & $\square$ tak & $\square$ nie \\
\hline PS.11.2. & $\begin{array}{l}\text { Wszystkie procesy związane } \mathrm{z} \text { przetwarzaniem danych osobowych } \\
\text { realizowane sa zgodnie z przyjetymi regulacjami. }\end{array}$ & $\square$ tak & $\square$ nie \\
\hline PS.11.3. & $\begin{array}{l}\text { Wszystkie procesy związane } \mathrm{z} \text { przetwarzaniem informacji niejawnych } \\
\text { realizowane są zgodnie z przyjętymi regulacjami. }\end{array}$ & $\square$ tak & $\square$ nie \\
\hline \multicolumn{4}{|c|}{ Standard S.12. Mechanizmy kontroli zarządczej } \\
\hline PS.12.1. & $\begin{array}{l}\text { Wszystkie dokumenty regulujące sposób zapewnienia standardów kon- } \\
\text { troli zarządczej są wprowadzone i aktualizowane stosownie do potrzeb. }\end{array}$ & $\square$ tak & $\square$ nie \\
\hline PS.12.2. & $\begin{array}{l}\text { Wszystkie główne dokumenty świadczące o zapewnieniu standardów } \\
\text { kontroli zarządczej są dostosowane do parametrów standardu. }\end{array}$ & $\square$ tak & $\square$ nie \\
\hline PS.12.3. & $\begin{array}{l}\text { Monitoring i ocena poziomu zapewnienia kontroli zarządczej prowadzo- } \\
\text { na jest minimum raz w roku kalendarzowym. }\end{array}$ & $\square$ tak & $\square$ nie \\
\hline
\end{tabular}

Źródło: Opracowanie własne.

Zgodnie z wytycznymi Ministra Finansów samoocena powinna się odbywać przynajmniej raz w roku. Zastosowanie przedstawionej Karty oceny... ukierunkowuje samoocenę na sparametryzowane aspekty kontroli zarządczej. Dzięki temu relatywnie łatwo można zdefiniować plan doskonalenia na kolejny rok, określając harmonogram działań pozwalających na osiągnięcie danego parametru.

\section{ANALIZA ZGODNOŚCI STANDARDÓW}

Przedstawione w niniejszym artykule standardy kontroli zarządczej są zgodne z wytycznymi Ministra Finansów przedstawionymi w Komunikacie nr 23 Ministra Finansów z dnia 16 grudnia 2009 r. w sprawie standardów kontroli zarządczej dla sektora finansów publicznych. Poniżej przedstawiono ocenę zgodności. 
Tabela 3. Tabela zgodności proponowanych standardów z wytycznymi Ministra Finansów

\begin{tabular}{|c|c|c|c|c|c|c|c|c|c|c|c|c|}
\hline \multirow[b]{2}{*}{ Ogólne standardy kontroli zarządczej } & \multicolumn{12}{|c|}{ Standardy kontroli zarządczej } \\
\hline & 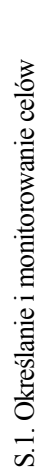 & 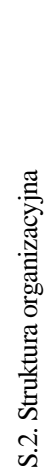 & 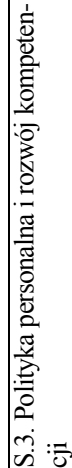 & 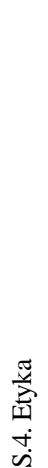 & 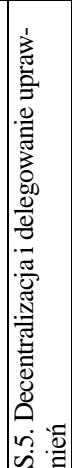 & 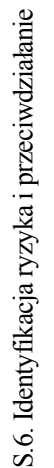 & 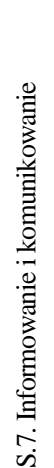 & $\begin{array}{l}\dot{\vec{N}} \\
\dot{0} \\
z \\
\infty \\
\infty \\
\dot{0}\end{array}$ & 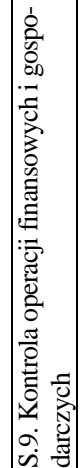 & 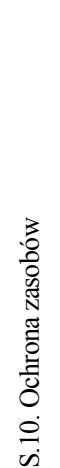 & 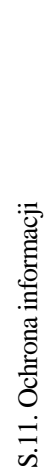 & 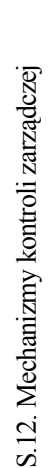 \\
\hline A.1. Przestrzeganie wartości etycznych & & & & & & & & & & & & \\
\hline A.2. Kompetencje zawodowe & & & & & & & & & & & & \\
\hline A.3. Struktura organizacyjna & & & & & & & & & & & & \\
\hline A.4. Delegowanie uprawnień & & & & & & & & & & & & \\
\hline B.1. Misja & & & & & & & & & & & & \\
\hline $\begin{array}{l}\text { B.2. Określanie celów i zadań, monitoro- } \\
\text { wanie i ocena ich realizacji }\end{array}$ & & & & & & & & & & & & \\
\hline B.3. Identyfikacja ryzyka & & & & & & & & & & & & \\
\hline B.4. Analiza ryzyka & & & & & & & & & & & & \\
\hline B.5. Reakcja na ryzyko & & & & & & & & & & & & \\
\hline
\end{tabular}

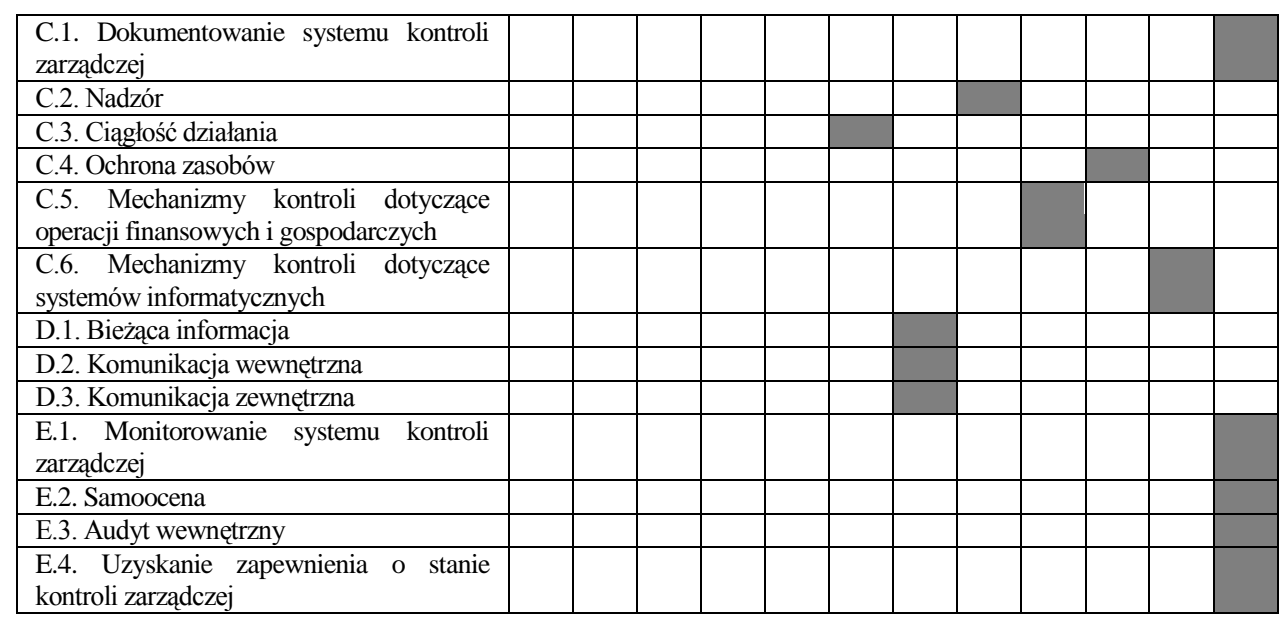

Źródło: Opracowanie własne na podstawie: J. Strojny, Standardy kontroli zarządczej (raport wdrożeniowy), materiały niepublikowane.

Oprócz odniesienia się do wytycznych Ministra Finansów, warto zweryfikować także zgodności proponowanych rozwiązań z ogólnymi celami kontroli zarządczej określonymi w art. 68 pkt. 2 ustawy z 29 sierpnia 2009 r. o finansach publicznych. Poniżej przedstawiono ocenę tego zagadnienia. 
Tabela 4. Tabela zgodności standardów

\begin{tabular}{|c|c|c|c|c|c|c|c|c|c|c|c|c|}
\hline \multirow[b]{2}{*}{ Ogólne standardy kontroli zarządczej } & \multicolumn{12}{|c|}{ Standardy kontroli zarządczej } \\
\hline & 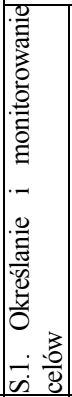 & 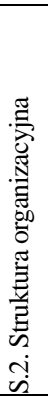 & 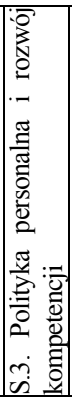 & 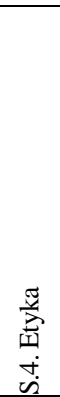 & 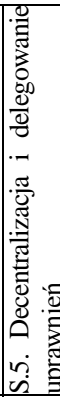 & 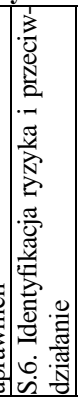 & 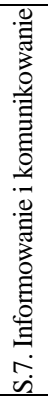 & 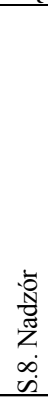 & 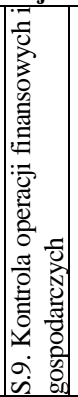 & 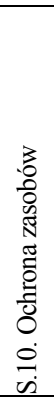 & 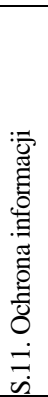 & 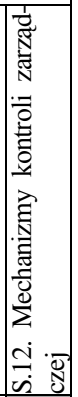 \\
\hline $\begin{array}{l}\text { 1. Zgodność działania z przepisami prawa } \\
\text { i procedurami wewnętrznymi }\end{array}$ & & & & & & & & & & & & \\
\hline 2. Skuteczność i efektywność działania & & & & & & & & & & & & \\
\hline 3. Wiarygodność sprawozdań & & & & & & & & & & & & \\
\hline 4. Ochrona zasobów & & & & & & & & & & & & \\
\hline $\begin{array}{l}\text { 5. Przestrzeganie i promowanie zasad } \\
\text { etycznego postępowania }\end{array}$ & & & & & & & & & & & & \\
\hline $\begin{array}{l}\text { 6. Efektywność i skuteczność przepływu } \\
\text { informacji }\end{array}$ & & & & & & & & & & & & \\
\hline 7. Zapewnienie zarządzania ryzykiem & & & & & & & & & & & & \\
\hline
\end{tabular}

Źródło: Opracowanie własne na podstawie: J. Strojny, Standardy kontroli zarzqdczej (raport wdrożeniowy), materiały niepublikowane.

Należy przyjąć, że poziom zapewnienia wyznaczonych ustawowo celów kontroli zarządczej będzie uzależniony od umiejętności osiaggania poszczególnych parametrów przypisanych do poszczególnych standardów. Stanowią one swego rodzaju zestawienie miar stopnia realizacji celu postawionego przed standardem. Warto jednak pamiętać, że propozycja przedstawiona aktualnie stanowi nie tylko zamknięcie kolejnego etapu doskonalenia kontroli zarządczej w badanej jednostce, ale także otwarcie nowego. Oznacza to, że katalog parametrów ma charakter otwarty i dynamiczny. W miarę osiagania pełnego zapewnienia wyznaczonych tutaj parametrów, warto wprowadzać kolejne, istotne z punktu widzenia pojawiających się przed jednostką wyzwań rozwojowych.

\section{PODSTAWOWE WNIOSKI}

Zapewnienie kontroli zarządczej wymaga wprowadzenia takich rozwiązań, które nie tylko wypełniają zapisy ustawowe, ale także przełożą się na faktyczne działanie w kierunku usprawnienia procesu zarządzania. Podejście przedstawione w niniejszym artykule pozwala na uzyskanie tego typu założeń. Przyjęta formuła jest elastyczna, ze względu na zastosowanie dedykowanego zestawu standardów, który jest zgodny z wytycznymi Ministra Finansów, ale zapewnia dostosowanie zapisów do wymagań danej jednostki samorządowej. Oczywiście, podczas wdrożenia należy przeprowadzić analizę, która pozwoli na sprecyzowanie listy standardów oraz odpowiednie ich opisanie. Podobne zalecenie należy przyjąć przy definiowaniu mierników. W każdej jednostce mogą one być sformułowane nieco inaczej. Zależy to od specyfiki jednostki, w tym - jej wielkości, poziomu zbiurokratyzowania procesów, wyposażenia w oprogramowanie wspierające zarządzanie, szczegółowych procedur, czy wprowadzonych regulacji wewnętrznych. 


\section{LITERATURA}

[1] Komunikat nr 23 Ministra Finansów z dnia 16 grudnia 2009 r. w sprawie standardów kontroli zarządczej dla sektora finansów publicznych, DzUrz. Min. Fin. nr 15, poz. 84.

[2] Kowalczyk E., Kontrola zarzqdcza w jednostce sektora finansów publicznych. Wzory procedur i instrukcji, Presscom, Wrocław 2010.

[3] Kuc B.R., Kontrola jako funkcja zarzadzania, Difin, Warszawa 2009.

[4] Strojny J., Standardy kontroli zarzqdczej (raport wdrożeniowy), materiały niepublikowane.

[5] Ustawa z dnia 27 sierpnia 2009 r. o finansach publicznych, DzU nr 157, poz. 1240, ze zm.

\section{STANDARDS OF INTERNAL CONTROL - PRACTICAL ASPECTS OF IMPLE- MENTATION}

The article presents the assumptions of implementation and improvement of management control system on the example of the JST. It was described the founding of a new approach to the management of the listed entities. The focus was put on the goals of management control, and its essence, referring to the general standards and setting on this basis, the most important areas. Some of them, such as risk management for public administration are relatively new and are a kind of challenge. Implementation of management control requires some changes in the meaning and organization of the management process. Unfortunately, the main problem is that, while introducing the management control one does not focus enough on the needs of the management process but the need to comply with the statutory provisions.

There were proposed standards tailored to the specifics of local self-government. Through an analysis of compliance with the guidelines laid down by the Minister of Finance it was also assessed the usefulness of this proposal and the possibility of its practical implementation. It should be noted that the scheme of management control system was built based on the list of standards is a general approach, but also comprehensively covers all important areas of management. Of course, the implementation of management control requires appropriate adjustment solutions (e.g., certain documents, or procedures) to the specifics of the organization. Therefore, half of the overall concept, which was presented in the article should be optimized in the implementation process to meet the individual needs of the entity.

Keywords: internal control, local government, standards, implementation

DOI: $10.7862 /$ rz.2013.mmr.10

Teks złożono w redakcji: styczeń 2013

Przyjęto do druku: czerwiec 2013 